Canadian Journal of Higher Education Revue canadienne d'enseignement supérieur

Volume 43, No. 1, 2013, pages 23-43

\title{
Differentiation and Diversification in Higher Education: The Case of Private, Faith-Based Higher Education in Manitoba
}

\author{
Dan Smith \\ University College of the North
}

\begin{abstract}
The central proposition of this article is that Manitoba's faith-based higher education institutions have become more accepted by, and more closely integrated into, the mainstream post-secondary system in the province. Drawing on theoretical work explaining change in higher education systems, the article examines legislative and policy actions by government, public universities, and the faith-based institutions themselves that have increased the legitimacy of the private, faith-based institutions.
\end{abstract}

\section{Résumé}

L’idée maîtresse de cet article est que les établissements confessionnels d'enseignement supérieur du Manitoba sont aujourd'hui plus acceptés et mieux intégrés qu'auparavant par le courant principal du système d'enseignement postsecondaire. À l'aide de travaux théoriques qui expliquent les changements apportés aux systèmes d'enseignement postsecondaire, l'article étudie les interventions législatives et politiques exercées par le gouvernement, les universités publiques et les établissements confessionnels, et qui ont accentué la légitimité des établissements confessionnels privés.

Faith-based education has played an important role in the development of higher education in Manitoba. The province's contemporary univeristy system resulted from uniting a community of religious colleges beginning in the late 180os (Gregor, 1974, 1995, 1997; Harris, 1976; Morton, 1957), and early religious influences on Manitoba's contemporary public university system included the Anglican, Baptist, Catholic, Mennonite, and United denominations. Today, faith-based, degree-granting institutions in Manitoba include the Canadian Mennonite University, Providence University College and Seminary (Evangeli- 
cal Christian), William and Catherine Booth University College (Salvation Army), and Steinbach Bible College (Mennonite). These institutions together enrolled approximately 1,500 students in 2009-2010, equivalent to $2.7 \%$ of the public university student body.

Faith-based institutions exist across Canada, often with the legislative sanction of their host provinces (Canadian Council on Learning, 2010), yet their place within post-secondary systems is unclear (Marsden, 1994), and they have generally been marginalized (Skolnik, 1997). This article argues that in Manitoba, any marginalization of these institutions has been reversing itself as these institutions achieved greater legitimacy through a process of de-differentiation that has accelerated significantly since the late 1990s, resulting in faith-based institutions being more heavily integrated into the province's mainstream post-secondary system.

To demonstrate this thesis, the article examines structural change in Manitoba's postsecondary system brought about through legislative and policy change by government, as well as through procedural changes by the private post-secondary institutions themselves. A challenge to examining structural change in post-secondary education is that "Canada does not have a clear framework for understanding the many changes that have occurred within the [post-secondary] sector over the past 15 years" (Canadian Council on Learning, 2010, p. 4). The article also uses van Vught's (2008) ideas on differentiation and diversity as conceptual tools to help explain structural change in post-secondary systems.

In pursuing its main argument, the article examines three areas. First, it seeks to determine what has happened in Manitoba's faith-based higher education institutions in relation to the overall higher education system in the province. Second, it identifies how this situation came about and then outlines what Manitoba's experience reveals about change in post-secondary systems generally.

This article examines not individual colleges and universities in Manitoba, but rather the system of higher (that is, degree-granting) education, a system that includes both public and private sector institutions, and since 2009 includes Manitoba's public community colleges as degree-granting institutions. ${ }^{1}$ Defining "private" versus "public" in the higher education sector is not easy (Levin, 2005; Orton, 2003; Rae, 1996). Definitional efforts refer to ownership, majority control on governing boards, funding arrangements, and the vehicle of incorporation (Levy, 1986; Orton, 2003); however, the diversity of institutional arrangements frustrates attempts to develop clear distinctions. Levy (1986) argued that the clearest expression of private and public status is "extant usage": an institution is private (or public) because everyone agrees that it is so. However, confusion persists. For example, Rae (1996) observed that Ontario's public universities refer to themselves as private to emphasize their autonomy from government.

Despite this poorly resolved definitional problem, the principal focus of Canada's higher education system continues to be on public institutions (Marshall, 2004a, 2004b; Marshall \& Eifert, 2004; Orton, 2003), with credibility and quality generally being established through public legislation: "If an institution was approved by the respective provincial government, it was deemed to be accredited" (Marshall \& Eifert, 2004, p. 3). Although the public nature of Canada's higher education system has endured for decades (Marshall, 2004b), most Canadian provinces have "accepted ... the validity of the private, not-for-profit, (primarily faith-based) degree-granting institutions. Most provinces have at least one such institution chartered to offer a limited range of undergraduate degrees" 
(Marshall \& Eifert, 2004, pp. 10-11; see also Marshall, 2004a, p. 80).

This article examines the place in Manitoba's larger post-secondary system of faithbased higher education. A theoretical model is presented to help establish a framework within which to situate developments in the province. The article then turns to an exposition and discussion of those developments before presenting conclusions.

\section{The Theoretical Context}

Change in higher education is complex and not always easily explained. Some have observed a tendency toward homogenization whereby institutions move toward higher levels within the system-often programmatically toward the provision of degrees and structurally toward university status (Canadian Council on Learning, 2010; Jones \& Skolnik, 2009; Skolnik, 2004, 2005). Others have observed countervailing tendencies regarding differentiation through the creation of new institutions, which may include amalgamations of existing institutions (Canadian Council on Learning, 2010). Faith-based higher education is not immune to these processes.

Understanding how higher education systems change is important for transparency for students (Canadian Council on Learning, 2010), for their families, and for employers. Further, structural change often involves legislative among other changes, and it may have lasting implications for other areas such as funding. Governments must also understand such change.

Van Vught's (2008) framework related to differentiation and diversification helps explain change in post-secondary systems. Differentiation, van Vught stated, is "the process in which new entities emerge in a system" of higher education (2008, p. 151), whereas diversity is "the variety of entities within a system" (p. 152). Van Vught distinguished between internal diversity (differences within institutions) and external diversity (differences between institutions). This paper focuses on the latter, and van Vught has detailed its various dimensions (2008, p. 152):

- Structural diversity: differences resulting from legal, policy, or historical foundations.

- Programmatic diversity: differences in the levels and/or types of programs offered.

- Reputational diversity: the perceived status and/or prestige of a given institution.

- Procedural diversity: differences in teaching, research, and service functions at an institution.

- Constituent diversity: differences in the backgrounds of students and staff.

- Systemic diversity: differences in institution type within a system.

- Ethics and values diversity: differences in institutions' social and cultural norms. Horta, Huisman, and Heitor (2008) cogently summed up the value of diversity, saying that it allows for:

increased availability of educational choice for learners, thus promoting wider access to higher education for everyone; enables institutions to match educational needs, learning styles, curricula, goals, learning ability and speed of learners; permits institutions to decide upon their focused institutional missions and activities (underlying here the linkage with the institution's location, resources and type of desired or available students); and guarantees the legitimacy of institutions by 
making them more responsive to a fast changing technologically based society, which is becoming ever more complex and diverse. (p. 147)

Greater diversity allows for greater responsiveness to the needs of students and to the needs of the local community and wider society (Canadian Council on Learning, 2010; Horta et al., 2008).

Van Vught believed that differences between diversification and differentiation were poorly understood, a common perspective in Canadian higher education (Canadian Council on Learning, 2010). Van Vught's (2008) framework includes two basic propositions. First, when faced with scarce resources, organizations adapt to general conditions perceived as being successful, leading to greater uniformity. In the current context, faith-based institutions may seek to appear similar to public institutions, by, for example, identifying themselves as universities. Accordingly, van Vught (2008) concluded that the pursuit of reputation (defined by van Vught as the subjective perception of the quality, influence, and trustworthiness of an institution) is important in understanding change in higher education institutions. Levin (2004) agreed, arguing that "institutional motives, such as legitimacy and prestige, and organizational behaviors ... drive organizational actions" (p. 2).

Van Vught's second proposition argued that, where the influence of academic norms and values is greater in a system, less diversity can be expected in that system. Here van Vught claimed that organizations' behaviour may conform to common practices, such as, for example, faith-based colleges adopting academic freedom provisions or governance arrangements common among public institutions, or making curricular changes to facilitate credit transfer agreements between different institutions.

According to van Vught, change in systems includes not only the emergence of new institutions, but also the transformation of existing institutions. This change is relativistic: the nature and extent of change in a given post-secondary system depends to some extent on the norms and perceived successes within the post-secondary environment itself.

Van Vught's work suggested methodological tools for studying change in higher education systems. As a first step, establish the level of uniformity of the system to set the context for change. Second, understand to what extent the institutions under study have integrated dominant academic values and norms.

The remainder of this article is organized as follows. The article presents a brief analysis of Manitoba's university system, with the object of understanding the level of uniformity. It then turns to an analysis of the changing relationships between faith-based education and public education institutions in Manitoba.

\section{Manitoba's Public University System}

Manitoba's public university system is relatively small, composed of four public universities: the University of Manitoba, the University of Winnipeg, Brandon University, and l'Universite de Saint-Boniface. Noteworthy is the level of uniformity in the system.

Structurally, the institutions are similar. Each is established by separate legislation, each has a bicameral system of governance with a senate and a governing board, as well as a president to lead the administration. Additionally, each of these universities has since 1967 come under the ambit of the provincial post-secondary intermediary agency, first the Universities Grants Commission and, after 1997, the Council on Post-Secondary Ed- 
ucation. This arrangement provides common processes for operating and capital funding, and a program approval process that has little regard for differences in each university-factors identified by Horta et al. (2008) as contributing to the homogenization of post-secondary systems. System-wide policies relating to items such as accountability and tuition are also governed by the intermediary agency and applied to the universities in similar ways. Each university enjoys independence in areas of academic policy, admissions, graduation, and the hiring of staff.

Manitoba's universities are also similar programmatically. Although each university offers a variety of undergraduate and graduate degrees, for reasons of cost containment (Saunderson, 1981), the University of Manitoba offers most professional programming, as well as the majority of master's and all doctoral programs in the system. Additionally, there is significant procedural similarity (for example, senate review and approval of programming, and regular program evaluations), as well as similar working conditions for faculty (for example, faculty organization, tenure, academic freedom, research release time, and sabbaticals).

In terms of the reputation of Manitoba's public universities, each shares commonalities. Each is established by provincial legislation, all are members of the Association of Universities and Colleges of Canada, all are authorized to grant degrees through The Degree Granting Act, each receives public funding, all are designated for purposes of student aid, all are approved by Manitoba's Department of Education for the purposes of teacher certification, and all are generally well regarded in the national and international academic community.

There is less similarity across the universities in terms of constituents. For instance, the chief distinguishing factor among students and staff at l'Université de Saint-Boniface is that the language of instruction is French. Brandon University's student constituency is primarily rural, in keeping with its southwestern location in the province and its status as the only university outside the province's capital of Winnipeg. Although the University of Winnipeg strives to focus on the inner city, its student population, like that of the University of Manitoba, is drawn from throughout Winnipeg and the province. Similarly, the norms of each university vary to some extent: each university shares similar priorities for teaching, research, and service, but seeks to fulfill these functions from their specific niche in the system, be that a province-wide reach (University of Manitoba), an urban focus (University of Winnipeg), a rural orientation (Brandon University), or French language of instruction (Université de Saint-Boniface).

Universities in Manitoba have much in common. From van Vught's perspective, the general uniformity in Manitoba's higher education environment is a significant factor when analyzing changes pursued by private faith-based institutions in the province.

\section{Faith-based Institutions in Manitoba}

Faith-based education is not without controversy, and tension is often felt between academic freedom and the religious mission (Burtchaell, 1998; Hollinger, 2002). This tension has been observed in hiring practices in Manitoba. For instance, the Canadian Association of University Teachers (CAUT) identified the Canadian Mennonite University and Providence University College as institutions that require faculty members to adhere to a statement of faith as a condition of employment, and in 2010 and 2012, respectively, 
CAUT added them to its "faith test list" as schools requiring faculty members to adhere to a such a statement of faith (CAUT, 2010a, 2010b, 2011, 2012).

Hiring practices at faith-based private institutions have been formally tested in Manitoba in two ways. First, in Schroen v. Steinbach Bible College (1999), the Manitoba Human Rights Commission heard and dismissed a discrimination complaint that Steinbach Bible College fired an accounting clerk because she was not Mennonite. The Commission ruled that religious conformity is a bona fide basis for discrimination, based on the expectation that all SBC staff share the Mennonite faith with the community. The Commission found that "everyone employed at SBC was expected to share in a faithful way with students espousing the Christian faith, as that was what SBC was all about" (Schroen, 1999).

Hiring practices and faith-based colleges were again explored in 2009 during a debate in the University of Manitoba Senate. Senate was debating a new master's program in Peace and Conflict Studies, a program offered jointly with the University of Winnipeg and Menno Simons College, a college of the Canadian Mennonite University. The Senate Committee on Academic Freedom advised that the provisions with respect to academic freedom provided at Menno Simons/CMU were "not equivalent to the unequivocal protection provided by those at the University of Manitoba" (University of Manitoba, 2009c, p. 122). Of particular concern were the "Mission, Faith, and Hiring" provisions that required, as a condition of employment and continuing employment, faculty members of Menno Simons College to adhere to a particular faith perspective (University of Manitoba, 2009c). Those opposing the program raised concerns that faculty at Menno Simons did not have the same freedoms as faculty at the University of Manitoba. Those supporting the program pointed to the Canadian Mennonite University's membership in AUCC, and that the proposed master's program had already been reviewed and approved by the University of Winnipeg Senate (University of Manitoba, 2009c), with the inference that the provisions of academic freedom associated with the Canadian Mennonite University and Menno Simons College had already been tested by two other academic entities, and found to be sufficient.

Ultimately, the University of Manitoba Senate approved the program, reflecting a comfort level with the Canadian Mennonite University's membership in AUCC, the review of the specific program in relation to academic freedom by the University of Winnipeg Senate, the merits of the program itself, and the fact that an undergraduate and a doctoral program in Peace and Conflict Studies exist in Manitoba's post-secondary system, but not a master's program. It is not unimportant, however, that a graduate program largely offered through a faith-based institution, was accepted by the University of Manitoba and the University of Winnipeg only after direct debate of the issue of academic freedom at faith-based institutions.

Schroen and the debate in the University of Manitoba Senate present cases where there appears to be tension, but interestingly a measure of acceptance of faith-based institutions, both in terms of their particular faith mission and in relation to the academic mission of the academy. The following pages take a more structured approach to examining developments relating to faith-based institutions in Manitoba over the long term, with the object of exploring this acceptance. Historical developments related to faith-based institutions, listed in the Appendix, will be examined in two major categories: government recognition and zones of mutual trust. 


\section{Government Recognition}

"Government recognition" is an ambiguous designation. Manitoba's Council on Post-Secondary Education (COPSE) comments on its website that "recognition" has no definition in Manitoba, and notes that there is no process of recognition (COPSE, n.d.). COPSE's website continues, referring to the Canadian Information Centre for International Credentials (CICIC), which "identifies a 'recognized' post-secondary institution as any institution that has been given the authority to grant academic credentials by their provincial or territorial government through charters or legislation that ensures or enables mechanisms for institutional and program quality" (COPSE, n.d.). CICIC includes a list of recognized institutions on its website, including the Manitoba's four faith-based, degree-granting institutions (CICIC, n.d.).

COPSE's website identifies a number of mechanisms by which the province acknowledges post-secondary institutions. Mechanisms relevant to degree-granting institutions include funding and program approval through COPSE, student loan designation, ministerial approval of academic programming leading to teacher certification, and inclusion in the degree authorization framework established by The Degree Granting Act (COPSE, n.d.).

Thus, using COPSE and CICIC as a starting point, it is possible to present an operational definition of recognition for degree-granting institutions in Manitoba that includes a number of dimensions that, taken together, suggest recognition by government (see Table 1 in the conclusion). To make a potentially long story short, a review of the history of private post-secondary education in Manitoba reveals that all four of the private, faith-based, degree-granting institutions fit into nearly all aspects of this operational definition.

A brief review of government's involvement in the development of the faith-based higher education system is revealing. Between 1925 and 1947, government was not involved in faith-based higher education, but there was increased activity beginning in 1948. From 1948 to 1997, "government recognition" consisted of actions that either established a faith-based institution in legislation or amended that legislation principally for the purpose of changing the institution's name. Overall, much of the government activity between 1948 and 1997 was related to the incorporation process or the naming process. This focus contrasts with the nature of government activity after 1997.

Beginning in 1998, government's activity more strongly reflected the recognition of faithbased higher education in the province. The increased involvement of government can in part be explained by a 1998 statement of the then-minister of education and training, the Honourable Linda McIntosh, to the Manitoba Legislative Assembly that "the independent colleges are an integral part of Manitoba's post-secondary system and have been for much of this century ... The need to incorporate the independent colleges under The Council on Post-Secondary Education Act comes from the initial desire as expressed in the [1993 Report of the University Education Review Commission] to ensure that Manitoba's post-secondary system is fully co-ordinated and articulated" (Manitoba, 1997). To date, this statement remains the only policy statement about faith-based higher education in Manitoba. Subsequent government action suggests that the integration of faithbased education into the larger system remained a policy objective.

Since 1998, government action also involved legislative or policy decisions. Legislative action included establishing the Canadian Mennonite University in 1998, the first, and to date only, private university in the province. At the same time, legislation was created to formalize a funding relationship with other faith-based colleges through a 1998 amendment to The Council on PostSecondary Education Act, as well as the reaffirmation of the degree-granting authority of each of 
these institutions through the creation of The Degree Granting Act in 2006. In 2009, a change in legislation was made to include the term university in the name of William and Catherine Booth University College. Similarly, in 2011, legislation was passed allowing Providence to change its name to Providence University College and Seminary.

Further, a series of non-legislative policy decisions were taken that suggests greater government recognition. These decisions include allowing international students attending private religious institutions to participate in federal-provincial employment programs, the inclusion of Providence University College and the Canadian Mennonite University in the Knowledge Infrastructure Program federal stimulus package, and the approval by COPSE of the use of the term university in advertising for two faith-based colleges. Additionally, in 2009, Manitoba Education authorized degrees from Providence University College and from William and Catherine Booth University College as eligible teachable subjects for the purposes of teacher certification for students entering education programs at a provincial university.

These actions, taken independently, demonstrate a growing government recognition of Manitoba's four faith-based institutions of higher education. In the absence of a de jure process of recognition, this article proposes that these dimensions represent de facto recognition of these institutions. Indeed, in the light of these legislative and policy actions, it may be impossible for government to argue that these institutions are not recognized.

Although government recognition of institutions is important, acceptance of faith-based institutions by the mainstream post-secondary system may be more important in terms of reputation and legitimacy. There is evidence that faith-based institutions in Manitoba have adapted to the academic norms and values commonly held by the public system through increased inter-institutional trust, discussed below.

\section{Zones of Mutual Trust}

Aldeman (2009) describes a "zone of mutual trust" (ZMT) as being established by a series of agreements on the delivery, recognition and evaluation of learning outcomes (knowledge, skills and competences). It can be formal or informal according to the mutual confidence and needs of the stakeholders involved. The details of the agreements between organisations can be used to build a framework of recognition based on levels of ... learning. (p. 16)

A ZMT is not imposed externally on an institution such as through legislation, for example, but rather arises from the system itself through agreements between institutions (Aldeman, 2009). Thus, a ZMT could be said to exist where there are credit transfer agreements in place, or one institution has an affiliation agreement with another.

In the Manitoba context, ZMTs exist between public and private post-secondary systems through credit transfer agreements, Approved Teaching Centre (ATC) status, affiliation agreements, and external processes such as accreditation and membership in national organizations (for example, the Association of Universities and Colleges of Canada). Another indicator that a ZMT exists includes participation in the Council of Presidents of Universities of Manitoba (COPUM), a forum similar to bodies such as the Council of Ontario Universities or Universities UK.

The concept of ZMTs links well with van Vught's (2008) perspective on institutional isomorphism, a perspective that stresses institutional adaptation to the presence of other 
organizations in the environment which "tend[s] to lead to homogenization, as organizations react more or less similarly to uniform environmental conditions. Isomorphism is a constraining process that forces organizations to resemble other organizations that face the same set of environmental conditions" (p. 154). The development of zones of mutual trust has in the case of Manitoba's post-secondary system led to the adoption by faithbased institutions of the academic norms held by public institutions.

For space reasons, this article will look at specific ZMTs selected because of their intentionality; that is, the extent to which the ZMT reflects an active decision on the part of a public institution to accept a faith-based college. Thus, while articulation (for example, credit transfer) arrangements may indicate a ZMT, credits accepted on a course-bycourse basis, or even acceptance of an entire program, may not necessarily reflect wider acceptance of an institution.

Although there are affiliation agreements in Manitoba, such as that between the Canadian Mennonite University and the University of Winnipeg, a structured affiliation arrangement that speaks to a broader acceptance of an institution as a centre of instruction is ATC status with the University of Manitoba. The ATC policy, established by the University of Manitoba in 1970, includes detailed criteria that must be met, including academic freedom for faculty at the ATC and related procedures of appeal and faculty protection. In addition, the qualifications of instructors must be equivalent to those at the University of Manitoba, credits must be approved by the relevant department at the University of Manitoba, and staff and students must be governed in academic matters by the same rules and regulations established by the University of Manitoba Senate for its own students and staff (University of Manitoba, 1994).

In 1992, the University of Manitoba granted William and Catherine Booth College (today a university college) ATC status, essentially accepting the courses and programs taught at Booth for academic credit (WCBC, 2010b). Similarly, the Canadian Mennonite Bible College, which has since been succeeded by the Canadian Mennonite University, also received ATC status.

However, the ATC relationship has not been embraced by all faith-based institutions, as suggested by an administrator at Providence University College and Seminary in Manitoba when considering ATC status: "I personally ... was leery of that, out of concerns lest we become mired in this academic freedom philosophical debate, having to make some kind of commitment to philosophical or theological pluralism as the sine qua non of academic freedom and legitimate university education" (Rae, 1998, p. 264).

William and Catherine Booth University College (Booth UC) had no such concerns, and indeed amended its internal processes in response to pressures placed on it with respect to academic freedom as a direct result of pursuing ATC status. In the report of the University of Manitoba Senate Committee on Approved Teaching Centres (SCATC) regarding the approval of Booth UC as an ATC, SCATC stated concerns that the teaching load of Booth UC faculty, at 24 credit hours, was out of line with current norms. SCATC noted in its report that Booth UC amended its policy, lowering the teaching load to 18 credit hours, something SCATC believed was more appropriate for university-level teaching (WCBC, 1999). Through revising its policies relating to academic teaching load, Booth UC made changes to gain ATC status, thereby improving its overall recognition within the larger post-secondary system.

A similar benefit, but one with national implications, is derived from membership in the Association of Universities and Colleges of Canada (AUCC). AUCC (n.d.) criteria 
represent important norms in Canada's higher education community, including degreegranting authority, governance arrangements "appropriate to a university" (including a senate or equivalent), an independent governing board, a focus on teaching, research, and service, and support for university autonomy, to name some key criteria.

The Canadian Mennonite University became a member of AUCC in 2008 (CMU, 2008). The impact of AUCC membership on the university was important, and CMU president Gerald Gerbrandt noted that it has been easier for students to gain access to Canadian and other graduate schools: "AUCC membership has been instrumental in opening these doors" (CMU, 2009a). AUCC membership helps to establish the credibility of an institution within the larger post-secondary community.

Finally, how one university perceives another within the larger framework of a postsecondary system is important. In June 2009, the University of Manitoba Senate voted to change the admissions procedures for graduate studies so as to allow students from "Canadian institutions empowered by law to grant degrees" eligibility for admission to the Faculty of Graduate Studies (Providence College and Seminary, 2009a; University of Manitoba, 2009a). Providence University College reported that "up to the present, the Faculty of Graduate studies maintained a list of schools with acceptable degrees. Providence was not on the list. Providence graduates generally had to complete a second Bachelors degree to enter graduate studies" (PCS, 2009a). The implication of this policy change for Providence, Booth UC, and Steinbach Bible College was that their students could gain admission to the University of Manitoba's graduate programs despite the institutions not being members of the AUCC (PCS, 2009a; WCBC, 2009) because each of these colleges is able to grant degrees in accordance with the framework established by the province's Degree Granting Act.

This change has been interpreted as a further acceptance of faith-based higher education in Manitoba. David Neal, vice-president (academic) at William and Catherine Booth University College, told the Winnipeg Free Press that "this change in the University of Manitoba's policy represents an evolution in their approach to faith-based colleges in the province ... It's a very positive development for us" (Longhurst, 2009, p. A9). Augustus Konkel, president of Providence University College, said that the change is "extremely important. It means that a degree from Providence is the same as any other degree in Canada" (Longhurst, 2009, p. A9). Clearly, the faith-based higher education institutions, at least, have perceived this policy change as meaning greater integration in the postsecondary system.

\section{Discussion and Conclusion}

This paper has identified several markers of acceptance of faith-based higher education in Manitoba (see Table 1). Acceptance has accrued over time through government recognition, as well as by the identification of zones of mutual trust by mainstream postsecondary institutions and the larger post-secondary community.

Together, these markers of acceptance help to lend legitimacy to the operations of faith-based institutions. Such legitimacy helps to improve the reputation of these institutions as well, as van Vught has indicated, improving the subjective perception of their quality, influence, and trustworthiness. Given the extent of the markers displayed in Table 1 , and the degree to which faith-based institutions have matched those same markers with 
Table 1

Dimensions of Legitimacy for Three Types of Institutions

\begin{tabular}{|c|c|c|c|}
\hline Dimension of Legitimacy & $\begin{array}{c}\text { Public } \\
\text { Colleges }\end{array}$ & $\begin{array}{c}\text { Public } \\
\text { Universities }\end{array}$ & $\begin{array}{l}\text { Faith-Based } \\
\text { Institutions }\end{array}$ \\
\hline \multicolumn{4}{|l|}{ a. Government Recognition } \\
\hline Established in Legislation & All & All & CMU, PUCS, WCBUC \\
\hline Funding From COPSE & All & All & All \\
\hline Programs Approved by COPSE & All & All & CMU (Limited) \\
\hline Accountability Requirements & All & All & All \\
\hline Designated for Student Aid & All & All & All \\
\hline Degree Authorization & All & All & All \\
\hline TECC-Approved & $\mathrm{n} / \mathrm{a}$ & All & CMU, PUCS, WCBUC \\
\hline "University" in Name & $\mathrm{n} / \mathrm{a}$ & All & CMU, PUCS, WCBUC \\
\hline Use "Canada Brand" & All & All & All \\
\hline Listed as "Recognized"on CICIC Website & All & All & All \\
\hline $\begin{array}{l}\text { Eligible for Off-Campus Work Program for } \\
\text { International Students (Federal-Provin- } \\
\text { cial Program) }\end{array}$ & All & All & All \\
\hline \multicolumn{4}{|l|}{ b. Zones of Mutual Trust } \\
\hline Articulation Agreements & All & All & All \\
\hline Approved Teaching Centre Status & $\mathrm{n} / \mathrm{a}$ & $\mathrm{n} / \mathrm{a}$ & CMU, WCBUC \\
\hline AUCC Member & $\mathrm{n} / \mathrm{a}$ & All & $\mathrm{CMU}$ \\
\hline COPUM Member & $\mathrm{n} / \mathrm{a}$ & All & CMU \\
\hline $\begin{array}{l}\text { Eligible for Acceptance in Graduate Stud- } \\
\text { ies at UM }\end{array}$ & $\mathrm{n} / \mathrm{a}$ & All & All \\
\hline
\end{tabular}

Acronyms:

AUCC - Association of Universities and Colleges of Canada

CICIC - Canadian Information Centre for International Credentials

CMU - Canadian Mennonite University

COPUM - Council of Presidents of Universities of Manitoba

COPSE - Council on Post-Secondary Education

PUCS - Providence University College and Seminary

SBC - Steinbach Bible College

TECC - Teacher Education Certification Committee

UM - University of Manitoba

WCBUC - William and Catherine Booth University College 
the public post-secondary system, it would be difficult indeed to say that the faith-based institutions were not recognized institutions. Recognition can be used by the institutions to suggest that they are legitimate post-secondary institutions offering quality programming that is trusted by governments, professional associations, and peers. In short, beginning in 1998 their reputation has improved in the context of the overall system.

The fact that so much of the development is government controlled-legislation, funding, policy-suggests broad agreement for the idea of bringing them into the mainstream, and the government is directly involved in this process. Interestingly, the observed developments span governments of different political stripes. Although support for private postsecondary education can be ideologically charged, the development of the private post-secondary system in Manitoba has not appeared to have been hampered by partisan politics.

The theoretical concepts introduced by van Vught contribute to our understanding of how higher education systems could both differentiate and diversify. By establishing the dimensions of diversification, van Vught created conceptual tools that allow one to observe increasing acceptance through, for example, adopting procedures related to the treatment of academic freedom to gain greater legitimacy within the academic community while at the same time pursuing a diversification agenda, such as continuing to focus on the niche market of education from a particular religious perspective.

Applying van Vught's conceptual framework to events in the history of faith-based higher education in Manitoba leads to two general conclusions. First, these institutions have sought to reduce structural, reputational, and procedural diversity, and they have been helped through decisions made by public universities. Interestingly enough, the evidence presented above does not suggest a pursuit of programmatic diversity, but instead suggests that these colleges appear to be working toward matching the structure, procedures, and the reputation of public universities.

Second, the faith-based institutions have incrementally redefined their relationships with the post-secondary system and with individual universities. Faith-based institutions have been integrated into the post-secondary funding and accountability processes, into policy frameworks such as degree authorization, the use of the "Canada Brand" in international marketing, and other benefits. Further, faith-based institutions are increasingly integrated with the public system through affiliation agreements and ATC status. It would seem, then, that since 1998 faith-based institutions have sought to offer their programming through the accepted model of post-secondary education. Membership in AUCC, and acceptance by and participation in COPUM, further suggests that the relationship between faith-based institutions and the larger post-secondary system has become closer.

These conclusions have meaning for Manitoba's post-secondary system, and they point to a question: whether or not the integration of faith-based post-secondary institutions in Manitoba's post-secondary system is a desirable development. This question suggests that better direction-setting for post-secondary education may be helpful. For example, van Vught (2008) noted that the California Master Plan has been successful in preventing the homogenization of that state's post-secondary system. Although "master planning" has not been the norm in Canadian provinces, longer-term system planning may at the very least force the issue of diversification and differentiation into open discussion.

Contributing to this discussion would be additional research that explored, on an institutional level, the internal changes in institutional mandates at faith-based institutions. 
Key questions for exploration would include whether or not these colleges are moving toward secularization, and if so, why. Such research would help to nuance and add depth to the understanding of how and why post-secondary systems are changing.

After nearly a decade and a half, the 1998 statement by Linda McIntosh remains the only policy statement on the subject despite the fact that more recent trends (for example, quality assurance) have contributed to the discussion surrounding private higher education in other provinces. As the development of the post-secondary education system in the province continues, Manitoba may need to engage in a more comprehensive assessment of the place of private religious education in the province's overall post-secondary system.

\section{References}

Aldeman, C. (2009). The Bologna process for US eyes: Re-learning higher education in the age of convergence. Washington, DC: Institute for Higher Education Policy. Retrieved from http://www.ihep.org/assets/files/EYESFINAL.pdf

Ambrose University College. (2010). About. Retrieved from http://www.ambrose. edu/about/ambrose/formation

Association of Universities and Colleges of Canada. (n.d.). Criteria to become an institutional member of AUCC. Retrieved from http://www.aucc.ca/about_us/ membership/criteria_e.html

Association of Universities and Colleges of Canada. (1988). Statement on academic freedom and institutional autonomy. Retrieved from http://www.aucc.ca/_pdf/english/ statements/1988/aucc_academic_freedom_e.pdf

Burtchaell, J. T. (1998). The dying of the light: The disengagement of colleges and universities from their Christian churches. Grand Rapids, MI, and Cambridge, England: William B. Eerdmans.

Canadavisa.com. (2007). International student off-campus work permit extended to private institutions. Retrieved from http://www.canadavisa.com/international-studentoff-campus-work-permit-extended-to-private-institutions-070917.html

Canadian Association of University Teachers (CAUT). (1999, Sept. 8). Trinity Western added to CAUT's faith test list [News release]. Retrieved from http://www.cautbulletin. ca/en_article.asp?SectionID $=1185 \&$ SectionName $=$ News $\&$ VolID $=286 \&$ VolumeNam $\mathrm{e}=\mathrm{No} \% 207 \&$ VolumeStartDate $=9 / 8 / 2009 \&$ EditionID $=30 \&$ EditionName $=$ Vol\%2O 56\&EditionStartDate $=1 / 9 / 2009 \&$ ArticleID $=2926$.

Canadian Association of University Teachers (CAUT). (2010a, Oct. 13). Crandall U added to faith test list [News release]. Retrieved from http://www.caut.ca.news_details. asp?nid-1576\&page $=490$

Canadian Association of University Teachers (CAUT). (2010b, Oct. 20). Canadian Mennonite University added to faith test list [News release]. Retrieved from http://www. caut.ca.news_details.asp?nid-1579\&page $=490$

Canadian Association of University Teachers (CAUT). (2011, March 16). Redeemer added to faith test list [News release]. Retrieved from http://www.caut.ca.news_details. asp?nid-1639\&page $=490$ 
Canadian Association of University Teachers (CAUT). (2012, March 8). Providence University College added to faith test list [News release]. Retrieved from http://www. caut.ca.news_details.asp?nid-1750\&page $=490$

Canadian Council on Learning. (2010). Navigating post-secondary education in Canada: The challenge of a changing landscape. Ottawa, ON: Author.

Canadian Information Centre for International Credentials. (n.d.). Recognized and authorized institutions in Manitoba. Retrieved from http://www.cicic.ca/en/post-sec.as px? sortcode $=2.16 .22 \&$ crit $=1 \&$ province $=\mathrm{mb}$

Canadian Mennonite University (CMU). (2009a, May 21). Graduate schools increasingly open to CMU students [News release]. CMU News. Retrieved from http:// www.cmu.ca/news/may21gradschools.html

Canadian Mennonite University (CMU). (2009b, May 25). CMU receives funding [News release]. CMU News. Retrieved from http://www.cmu.ca/news/may25chemlab. html

Canadian Mennonite University (CMU). (2008, Oct. 23). CMU joins Association of Universities and Colleges of Canada [News release]. Retrieved from http://www.cmu.ca/ news/aucc.html

Council on Post-Secondary Education (COPSE). (2003). Statistical compendium. Winnipeg, MB: Author.

Council on Post-Secondary Education (COPSE). (2009). Annual report 2008/o9. Winnipeg, MB: Author.

Dennison, J. D., \& Schuetze, H. G. (2004). Extending access, choice, and the reign of the market: Higher education reforms in British Columbia, 1989-2004. Canadian Journal of Higher Education, 34(3), 13-38.

Gregor, A. D. (1974). The federated university structure in Manitoba (Doctoral dissertation). Michigan State University, Lansing, Michigan.

Gregor, A. D. (1995). Higher education in Manitoba. Occasional Papers in Higher Education, No. 5, Winnipeg, MB: Centre for Higher Education Research and Development.

Gregor, A. D. (1997). Higher education in Manitoba. In G.A. Jones (Ed.), Higher education in Canada: Different systems, different perspectives (pp. 115-135). New York, NY, and London, England: Garland.

Harris, R. S. (1976). A history of higher education in Canada 1663-1960. Toronto, ON: University of Toronto Press.

Hollinger, D. A. (2002). Universities do not need more Christianity. In A. Sterk (Ed.), Religion, scholarship and higher education (pp. 40-49). Notre Dame, IL: University of Notre Dame Press.

Horta, H., Huisman, J., \& Heitor, M. (2008). Does competitive research funding encourage diversity in higher education? Science and Public Policy, 35(3), 146-158. 
Jones, G. A., \& Skolnik, M. L. (2009). Degrees of opportunity: Broadening student access by increasing institutional differentiation in Ontario higher education. Toronto, ON: Higher Education Quality Council of Ontario.

Levin, J. S. (2004). The community college as a baccalaureate-granting institution. Review of Higher Education, 28(1), 1-22.

Levin, B. (2005). Governing education. Toronto, ON: University of Toronto Press.

Levy, D. C. (1986). "Private" and "public" analysis amid ambiguity in higher education. In D. C. Levy (Ed.), Private education: Studies in choice and public policy (pp. 170-192). New York, NY: Oxford University Press.

Longhurst, J. (2009, July 19). U of M helps keep religious studies students here. Winnipeg Free Press, p. A9. Retrieved from http://www.winnipegfreepress.com/life/ faith/u-of-m-helps-keep-religious-studies-students-here-51132647.html

Manitoba. (1997, April 18). Debates and proceedings (Hansard). Retrieved from http://www.gov.mb.ca/legislature/hansard/3rd-36th/vol_029/ho29_5.html

Marsden, G. M. (1994). The soul of the American university: From Protestant establishment to established nonbelief. New York, NY, and Oxford, England: Oxford University Press.

Marshall, D. (2004a). Access to degrees in the knowledge economy. Policy Options, 25(7), 76-82.

Marshall, D. (2004b). Degree accreditation in Canada. Canadian Journal of Higher Education, 3 (2), 69-96.

Marshall, D., \& Eifert, J. (2004, February). Degree accreditation in Canada. Paper presented at the International Consortium for Education and Economic Development, Cancún, Quintana Roo, Mexico.

Morton, W. L. (1957). One university: A history of the University of Manitoba 18771952. Toronto, ON: McClelland \& Stewart.

Orton, L. (2003). A new understanding of postsecondary education in Canada: A discussion paper. Ottawa, ON: Statistics Canada.

Providence College and Seminary (PCS). (2009a, June 30). Providence degrees recognized by University of Manitoba [News release]. Retrieved from http://prov.ca/ NewsReleases/NewsRelease.aspx?id=180

Providence College and Seminary (PCS). (2009b, July 18). Providence receives infrastructure grant from federal government [News release]. Retrieved from http:// prov.ca/NewsReleases/NewsRelease.aspx?id $=183$

Providence College and Seminary (PCS). (2009c, July 20). Providence degrees receive more recognition [News release]. Retrieved from http://prov.ca/NewsReleases/ NewsRelease. $\operatorname{aspx}$ ?id $=184$

Rae, P. S. (1996). New directions: privatization and higher education in Alberta. Canadian Journal of Higher Education, 26(2), 59-80.

Rae, P. S. (1998). Unholy alliance? The church and higher education in Canada (Unpublished doctoral dissertation). University of Manitoba, Winnipeg. 
Saunderson, H.H. (1981). The Saunderson Years. Winnipeg: University of Manitoba.

Schroen v. Steinbach Bible College (1999), 35 C.H.R.R. D/1 (Man./Bd.Adj.).

Skolnik, M. L. (1997). Putting it all together. In G.A. Jones (Ed.). Higher education in Canada: Different systems, different perspectives (pp. 325-341). New York, NY, and London, England: Garland.

Skolnik, M. L. (2004, Feb.). Does structure matter: (Where) do questions about structure fit on the higher education policy agenda? Prepared for the Higher Education in Canada Conference, Queen's University, Kingston, ON.

Skolnik, M. L. (2005). The case for giving greater attention to structure in higher education policy-making. In C.M. Beach, R.W. Broadway and M. McInnis (Eds.), Higher education in Canada (pp. 53-75). Montreal, QC, \& Kingston, ON: McGill-Queen's University Press.

University of Manitoba. (1994). Approved teaching centres [Policy]. Retrieved from http://www.umanitoba.ca/admin/governance/governing_documents/academic/345.htm

University of Manitoba. (2009a, June 24). Senate minutes. Winnipeg, MB: Office of the University Secretary.

University of Manitoba (2009b, March 17). Agenda: Board of Governors open session. Retrieved from http://umanitoba.ca/admin/governance/media/bogopen-marcho9_ complete.pdf

University of Manitoba. (2009c, Feb. 4). Senate minutes. Winnipeg, MB: Office of the University Secretary.

van Vught, F. (2008). Mission diversity and reputation in higher education. Higher Education Policy, 21, 151-174.

William and Catherine Booth College [WCBC]. (1999). William and Catherine Booth College candidacy application 1999: Social work programme. Winnipeg: Author.

William and Catherine Booth College (WCBC). (2009, July 3). Booth Grads can now apply for graduate studies at U of M [News release]. News Items. Retrieved from http:// www.boothcollege.ca/node/511

William and Catherine Booth College. (2010a). Teacher education at Booth takes a step forward [Web log post 19 July 2010]. Retrieved from http://www.boothuc.ca/currentstudents/blog/teacher-education-booth-takes-step-forward

William and Catherine Booth College. (2010b). Academic calendar 2010/11. Retrieved from http://www.boothcollege.ca/system/files/fm/2010-2011_Academic_Calendar.pdf

\section{Notes}

1 Although they are degree-granting institutions, community colleges and the University College of the North are generally excluded from detailed analysis. Practically, this exclusion is for reasons of space and, more substantively, because community colleges and the University College of the North provide different educational outcomes than faith-based institutions. 


\section{Contact Information}

Dan Smith

University College of the North

504 Princeton Drive

Thompson MB R8N oA5 Canada

dsmith@ucn.ca

Dan Smith is Dean of Arts and Science at University College of the North, and has a Ph.D. from the University of Manitoba. Prior to working at UCN, Dr. Smith worked at Manitoba's Council on Post-Secondary Education. The conclusions of this article are those of the author alone. The author is grateful for the comments of the anonymous reviewers, and all remaining errors and omissions are the author's. 
Appendix

Timeline of Key Events

\begin{tabular}{|c|c|c|c|}
\hline Event & Category & $\begin{array}{l}\text { Governing } \\
\text { Party }\end{array}$ & Comments \\
\hline $\begin{array}{l}\text { Winnipeg Bible Training } \\
\text { School established }\end{array}$ & & $\begin{array}{l}\text { United } \\
\text { Farmers of } \\
\text { Manitoba }\end{array}$ & $\begin{array}{l}\text { Became Providence College } \\
\text { and Seminary in } 1992\end{array}$ \\
\hline $\begin{array}{l}\text { "Bible School" established } \\
\text { by the Steinbach Mennonite } \\
\text { Brethren Church }\end{array}$ & & Progressives & $\begin{array}{l}\text { Became Steinbach Bible Col- } \\
\text { lege in } 1974\end{array}$ \\
\hline Bible School discontinued & & $\begin{array}{l}\text { Liberal } \\
\text { Progressives }\end{array}$ & $\begin{array}{l}\text { Became Steinbach Bible Col- } \\
\text { lege in } 1974\end{array}$ \\
\hline $\begin{array}{l}\text { Classes at Steinbach Men- } \\
\text { nonite Brethren Church } \\
\text { resumed }\end{array}$ & & $\begin{array}{l}\text { Liberal } \\
\text { Progressives }\end{array}$ & $\begin{array}{l}\text { Became Steinbach Bible Col- } \\
\text { lege in } 1974\end{array}$ \\
\hline $\begin{array}{l}\text { Mennonite Brethren Bible } \\
\text { College (MBBC) established }\end{array}$ & & $\begin{array}{l}\text { Liberal } \\
\text { Progressives }\end{array}$ & $\begin{array}{l}\text { Became Concord College in } \\
1992\end{array}$ \\
\hline $\begin{array}{l}\text { Canadian Mennonite Bible } \\
\text { College established }\end{array}$ & & $\begin{array}{l}\text { Liberal } \\
\text { Progressives }\end{array}$ & \\
\hline $\begin{array}{l}\text { Winnipeg Bible Training } \\
\text { School changes name to } \\
\text { Winnipeg Bible Institute } \\
\text { (WBI) and College of The- } \\
\text { ology and is established in } \\
\text { legislation }\end{array}$ & GR & $\begin{array}{l}\text { Liberal } \\
\text { Progressives }\end{array}$ & $\begin{array}{l}\text { Became Providence College } \\
\text { and Seminary in } 1992\end{array}$ \\
\hline $\begin{array}{l}\text { Canadian Nazarene College } \\
\text { moves to Manitoba from } \\
\text { Alberta }\end{array}$ & & $\mathrm{PC}$ & $\begin{array}{l}\text { Returned to Alberta in } 1995, \\
\text { and became Ambrose Univer- } \\
\text { sity College in } 2008\end{array}$ \\
\hline $\begin{array}{l}\text { MBBC enters into an af- } \\
\text { filiation agreement with } \\
\text { Waterloo Lutheran Univer- } \\
\text { sity (later Wilfrid Laurier } \\
\text { University) }\end{array}$ & ZMT & $\mathrm{PC}$ & $\begin{array}{l}\text { Eventually became Concord } \\
\text { College }\end{array}$ \\
\hline $\begin{array}{l}\text { WBI renamed Winnipeg } \\
\text { Bible College (WBC) and } \\
\text { adds a degree program }\end{array}$ & GR & $\mathrm{PC}$ & $\begin{array}{l}\text { Became Providence College } \\
\text { and Seminary in } 1992\end{array}$ \\
\hline $\begin{array}{l}\text { Canadian Nazarene College } \\
\text { established in law in Mani- } \\
\text { toba }\end{array}$ & GR & $\mathrm{PC}$ & By private member's bill \\
\hline $\begin{array}{l}\text { University of Manitoba } \\
\text { establishes the Approved } \\
\text { Teaching Centres policy }\end{array}$ & ZMT & $\mathrm{PC}$ & $\begin{array}{l}\text { Approves the practice of estab- } \\
\text { lishing centres of instruction } \\
\text { with authority to offer Uni- } \\
\text { versity of Manitoba courses in } \\
\text { other geographical areas }\end{array}$ \\
\hline
\end{tabular}




\begin{tabular}{|c|c|c|c|}
\hline Event & Category & $\begin{array}{l}\text { Governing } \\
\text { Party }\end{array}$ & Comments \\
\hline $\begin{array}{l}\text { MBBC agrees with Univer- } \\
\text { sity of Winnipeg to cross- } \\
\text { register students }\end{array}$ & ZMT & NDP & $\begin{array}{l}\text { Eventually became Concord } \\
\text { College }\end{array}$ \\
\hline $\begin{array}{l}\text { Canadian Nazarene Col- } \\
\text { lege becomes an Approved } \\
\text { Teaching Centre of the Uni- } \\
\text { versity of Manitoba. }\end{array}$ & $\mathrm{ZMT}$ & NDP & $\begin{array}{l}\text { See Ambrose University Col- } \\
\text { lege (2010) }\end{array}$ \\
\hline $\begin{array}{l}\text { Steinbach Bible College } \\
\text { incorporated }\end{array}$ & & NDP & $\begin{array}{l}\text { Through Letters Patent (an } \\
\text { older term for articles of incor- } \\
\text { poration) }\end{array}$ \\
\hline $\begin{array}{l}\text { Menno Simons College es- } \\
\text { tablished in legislation }\end{array}$ & GR & NDP & \\
\hline $\begin{array}{l}\text { Catherine Booth Bible Col- } \\
\text { lege (CBBC) established in } \\
\text { legislation }\end{array}$ & GR & NDP & $\begin{array}{l}\text { Became William and Catherine } \\
\text { Booth College in } 1996\end{array}$ \\
\hline $\begin{array}{l}\text { Menno Simons becomes } \\
\text { an affiliated college at the } \\
\text { University of Winnipeg }\end{array}$ & ZMT & $\mathrm{PC}$ & \\
\hline $\begin{array}{l}\text { MBBC becomes Concord Col- } \\
\text { lege }\end{array}$ & & $\mathrm{PC}$ & $\begin{array}{l}\text { Removes the term Bible from } \\
\text { name }\end{array}$ \\
\hline $\begin{array}{l}\text { Booth College becomes an } \\
\text { approved teaching centre of } \\
\text { the University of Manitoba }\end{array}$ & ZMT & $\mathrm{PC}$ & $\begin{array}{l}\text { Allows for ease of credit trans- } \\
\text { fer }\end{array}$ \\
\hline $\begin{array}{l}\text { WBC legislation amended to } \\
\text { change name to Providence } \\
\text { College and Seminary }\end{array}$ & GR & $\mathrm{PC}$ & $\begin{array}{l}\text { Removes the term Bible from } \\
\text { name }\end{array}$ \\
\hline $\begin{array}{l}\text { Canadian Nazarene College } \\
\text { moves to Calgary, Alberta }\end{array}$ & & $\mathrm{PC}$ & $\begin{array}{l}\text { Decision made in } 1994 \text { and } \\
\text { since } 2007 \text { known as Ambrose } \\
\text { University College (Ambrose } \\
\text { University College, 2010) }\end{array}$ \\
\hline $\begin{array}{l}\text { CBBC changes name to Wil- } \\
\text { liam and Catherine Booth } \\
\text { College (WCBC) }\end{array}$ & GR & $\mathrm{PC}$ & $\begin{array}{l}\text { By private member's bill and } \\
\text { removes the term Bible from } \\
\text { name }\end{array}$ \\
\hline $\begin{array}{l}\text { Section } 27.1 \text { added to } \\
\text { COPSE Act }\end{array}$ & GR & $\mathrm{PC}$ & $\begin{array}{l}\text { Providence College, William } \\
\text { and Catherine Booth College, } \\
\text { and Steinbach Bible College } \\
\text { brought into formal funding } \\
\text { arrangement }\end{array}$ \\
\hline
\end{tabular}




\begin{tabular}{|c|c|c|c|}
\hline Event & Category & $\begin{array}{l}\text { Governing } \\
\text { Party }\end{array}$ & Comments \\
\hline $\begin{array}{l}\text { Mennonite Colleges Federa- } \\
\text { tion (MCF) Act established }\end{array}$ & GR & $\mathrm{PC}$ & $\begin{array}{l}\text { Ultimately became CMU, and } \\
\text { was created by an amalga- } \\
\text { mation of Concord College, } \\
\text { Menno Simons College, and } \\
\text { CMBC }\end{array}$ \\
\hline $\begin{array}{l}\text { MCF renamed Canadian } \\
\text { Mennonite University }\end{array}$ & GR & NDP & $\begin{array}{l}\text { Private university created; a } \\
\text { consequence of the MCF Act, } \\
\text { allowing the institution to use } \\
\text { the term university }\end{array}$ \\
\hline $\begin{array}{l}\text { WCBC broadens degree- } \\
\text { granting authority, role of } \\
\text { minister; establishes "pur- } \\
\text { poses and objects" }\end{array}$ & GR & NDP & $\begin{array}{l}\text { Private member's bill spon- } \\
\text { sored by a government MLA }\end{array}$ \\
\hline $\begin{array}{l}\text { Private religious higher edu- } \\
\text { cation institutions included } \\
\text { in Statistical Compendium }\end{array}$ & GR & NDP & $\begin{array}{l}\text { A decision of COPSE based } \\
\text { on the fact that they get fund- } \\
\text { ing, with institutions included } \\
\text { since the first edition of the } \\
\text { Statistical Compendium }\end{array}$ \\
\hline $\begin{array}{l}\text { Private religious higher edu- } \\
\text { cation institutions brought } \\
\text { into degree-granting frame- } \\
\text { work through The Degree } \\
\text { Granting Act }\end{array}$ & GR & NDP & \\
\hline $\begin{array}{l}\text { International students at } \\
\text { private institutions allowed } \\
\text { to participate in the federal } \\
\text { government's Post-Gradu- } \\
\text { ate Work Permit Program }\end{array}$ & GR & NDP & $\begin{array}{l}\text { A federal government decision } \\
\text { at the recommendation from } \\
\text { the province, which had to } \\
\text { indicate that the participating } \\
\text { institutions were authorized } \\
\text { to grant degrees (Canadavisa. } \\
\text { com, 2007) }\end{array}$ \\
\hline CMU gets AUCC status & $\mathrm{ZMT}$ & NDP & $\begin{array}{l}\text { An AUCC decision, an inde- } \\
\text { pendent body; CMU students } \\
\text { are therefore eligible to be } \\
\text { certified as teachers in accor- } \\
\text { dance with Teacher Education } \\
\text { Certification Committee rules }\end{array}$ \\
\hline $\begin{array}{l}\text { WCBC allowed to use the } \\
\text { term university in advertis- } \\
\text { ing }\end{array}$ & GR & NDP & $\begin{array}{l}\text { A COPSE decision based on } \\
\text { delegated powers under The } \\
\text { Degree Granting Act }\end{array}$ \\
\hline
\end{tabular}




\begin{tabular}{|c|c|c|c|}
\hline Event & Category & $\begin{array}{l}\text { Governing } \\
\text { Party }\end{array}$ & Comments \\
\hline $\begin{array}{l}\text { Private religious higher edu- } \\
\text { cation institutions included } \\
\text { in Manitoba Graduate } \\
\text { Survey }\end{array}$ & GR & NDP & $\begin{array}{l}\text { A decision of Manitoba Ad- } \\
\text { vanced Education and Literacy } \\
\text { (colleges were not included in } \\
\text { previous surveys) }\end{array}$ \\
\hline $\begin{array}{l}\text { University of Manitoba } \\
\text { changes graduate studies } \\
\text { admissions procedures }\end{array}$ & ZMT & NDP & $\begin{array}{l}\text { Connects eligibility to legal au- } \\
\text { thority to grant degrees rather } \\
\text { than AUCC membership }\end{array}$ \\
\hline $\begin{array}{l}\text { Manitoba Education chang- } \\
\text { es education certification } \\
\text { provisions, allowing Provi- } \\
\text { dence and Booth grads to be } \\
\text { certified as teachers similar } \\
\text { to graduates from public } \\
\text { universities in Manitoba }\end{array}$ & GR & NDP & $\begin{array}{l}\text { A directive to the Teacher Edu- } \\
\text { cation Certification Committee } \\
\text { by the education minister }\end{array}$ \\
\hline $\begin{array}{l}\text { CMU receives Knowledge } \\
\text { Infrastructure Program } \\
\text { (KIP) funding, cost shared } \\
\text { with the federal and provin- } \\
\text { cial government }\end{array}$ & GR & NDP & $\begin{array}{l}\text { No prior capital support to } \\
\text { CMU since its establishment in } \\
1998\end{array}$ \\
\hline $\begin{array}{l}\text { Providence receives KIP } \\
\text { funding, but only from the } \\
\text { federal government }\end{array}$ & GR & $\begin{array}{l}\text { Federal Con- } \\
\text { servatives }\end{array}$ & $\begin{array}{l}\text { Not a shared-cost project with } \\
\text { the province, unlike other KIP } \\
\text { projects. }\end{array}$ \\
\hline $\begin{array}{l}\text { Providence request to use } \\
\text { university in advertising } \\
\text { approved by COPSE }\end{array}$ & GR & NDP & \\
\hline $\begin{array}{l}\text { WCBC changes its name } \\
\text { to William and Catherine } \\
\text { Booth University College } \\
\text { (WCBUC) }\end{array}$ & GR & NDP & $\begin{array}{l}\text { A legislative change to a pri- } \\
\text { vate act introduced by a gov- } \\
\text { ernment MLA; the request re- } \\
\text { ceived by COPSE and referred } \\
\text { to the Legislative Assembly }\end{array}$ \\
\hline $\begin{array}{l}\text { WCBUC signs an agreement } \\
\text { with University of Winnipeg } \\
\text { for credit transfer into the } \\
\text { teacher education program }\end{array}$ & ZMT & NDP & \\
\hline $\begin{array}{l}\text { Providence requests to use } \\
\text { term university in name } \\
\text { referred to Legislative As- } \\
\text { sembly by COPSE }\end{array}$ & GR & NDP & $\begin{array}{l}\text { Consistent with the } 2010 \\
\text { WCBC decision. }\end{array}$ \\
\hline $\begin{array}{l}\text { Providence College and } \\
\text { Seminary changes name to } \\
\text { Providence University Col- } \\
\text { lege and Seminary (PUCS) }\end{array}$ & GR & NDP & $\begin{array}{l}\text { A legislative change to a pri- } \\
\text { vate act introduced by a gov- } \\
\text { ernment MLA }\end{array}$ \\
\hline
\end{tabular}

